University of Nebraska - Lincoln

DigitalCommons@University of Nebraska - Lincoln

1982

\title{
Distribution Ecology: Variation in Plant Recruitment over a Gradient in Relation to Insect Seed Predation
}

Svata M. Louda

University of Nebraska - Lincoln, slouda1@unl.edu

Follow this and additional works at: https://digitalcommons.unl.edu/bioscilouda

Part of the Ecology and Evolutionary Biology Commons

Louda, Svata M., "Distribution Ecology: Variation in Plant Recruitment over a Gradient in Relation to Insect Seed Predation" (1982). Svata M. Louda Publications. 17.

https://digitalcommons.unl.edu/bioscilouda/17

This Article is brought to you for free and open access by the Papers in the Biological Sciences at DigitalCommons@University of Nebraska - Lincoln. It has been accepted for inclusion in Svata M. Louda Publications by an authorized administrator of DigitalCommons@University of Nebraska - Lincoln. 


\title{
DISTRIBUTION ECOLOGY: VARIATION IN PLANT RECRUITMENT OVER A GRADIENT IN RELATION TO INSECT SEED PREDATION ${ }^{1}$
}

\author{
SVAŤA M. LOUdA ${ }^{2}$ \\ Biology Department, San Diego State University, San Diego, California 92182, and \\ Department of Biological Sciences, University of California, \\ Riverside, California 92705 USA
}

\begin{abstract}
Although predispersal seed predation by insects is common, no test exists of its effect on plant recruitment. This study examines seed predation in the population dynamics of a native, temperate shrub, Haplopappus squarrosus H. and A. (Asteraceae), over an elevational gradient in the coastal sage scrub vegetation of San Diego County, California USA. Frequency and abundance of $H$. squarrosus increase from coast to mountains. Expected abundance, based on flowers initiated, was highest at the coast and lowest in the interior, the opposite of the observed adult plant distribution. Overall flower and seed predation by insects was high (44-73\%) and was greatest at the coast. Insect exclusion experiments at sites along the gradient had three main results. (1) Seedling recruitment was proportional to the number of viable seeds after seed predation. The exclusion plots had significantly higher numbers of seedlings established at all sites than did control plots; the greatest increase was at the coast. (2) Seedling survivorship was independent of both seedling and adult densities. (3) Juvenile recruitment was proportional to seedling establishment. Predation by insects prior to release of seeds played a critical role in the population recruitment of $H$. squarrosus within and among sites along the gradient. Survivorship of established plants, in addition, was as high at the coast as it was in the interior. These results suggest that indigenous insect seed predators can be a major force controlling the dynamics of a native plant species over its natural distributional range.
\end{abstract}

Key words: Asteraceae (Compositae); geographical ecology; gradient; Haplopappus; herbivores; insect-plant interaction; phytophagous insects; plant population dynamics; seed predation; vegetation gradient.

\section{INTRODUCTION}

The question, "What determines plant distribution and density?" has always been a central one in plant ecology (e.g., Darwin 1859, 1958:78, Salisbury 1942, Billings 1964, Whittaker 1970, Barbour et al. 1980). The role of herbivory in a comprehensive answer to that question has recently begun to receive increased attention (Harper 1969, 1977, Janzen 1970, Connell 1971, Harris 1972). An abundance of indirect evidence, in addition, suggests that predispersal seed predation by insects may be critically important in plant dynamics (e.g., Janzen 1971b, Harper 1977, Louda 1978). However, the effect of predispersal seed loss on seedling recruitment and adult numbers needs to be tested directly (Harper 1977: Chapter 15, Louda 1978).

Seed predation, like other forms of predation, theoretically should cause two types of response by the exploited plant population. The first is adaptation, via selection for morphological, chemical, temporal, and spatial mechanisms of predator avoidance (e.g., Ehrlich and Raven 1965, 1967, Whittaker and Feeny 1971, Rosenthal and Janzen 1979). The second is modifica-

\footnotetext{
${ }^{1}$ Manuscript received 19 May 1980; revised 12 May 1981; accepted 1 June 1981.

${ }^{2}$ Present address: Duke University Marine Laboratory, Beaufort, North Carolina 28516 USA.
}

tion of numerical and spatial occurrence, via elimination and redistribution of better adapted individuals in the population through differential patterns of attack (e.g., Ricker 1954a, b, Huffaker and Kennett 1959, Mech 1966, Cantlon 1969, Harper 1969, Janzen 1969, 1971a, c, 1975c, Louda 1978).

The adaptive response of plants to insect herbivore pressure is well documented (e.g., Feeny 1975, 1976, Rhoades and Cates 1976, Cates and Rhoades 1977, and references above). The numerical response is not as well understood (Cantlon 1969, Harper 1969, 1977, Janzen 1969, Harris 1972, Willson 1973, Manley et al. 1975, Louda 1978).

The evidence available on predispersal seed predation, however, suggests that such losses may be very important in host plant dynamics. First, losses can be intense, repeated, and widespread (e.g., reviews by: Salisbury 1942, Janzen 1971b, Louda 1978). Second, experimental reduction in flower or seed predation can cause significant increases in the number of viable seeds matured and released (Breedlove and Ehrlich 1968, 1972, Waloff and Richards 1977, Louda 1978, 1982). Third, since differential damage by foliage-feeding herbivores can influence plant abundance and distribution (e.g., Huffaker and Kennett 1959, Harper 1969, Goeden 1978), differential damage by seed-feeding insects may have comparable effects. Leaf loss to herbivores, for example, can vary among plants in ad- 
San Diego County

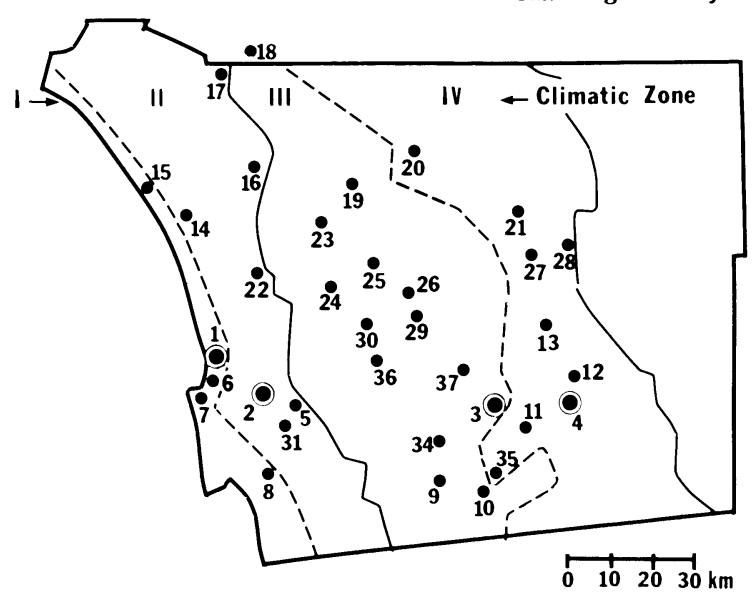

Fig. 1. Climatic zones and location of sites in San Diego County in the southwest corner of California. Oceanic influence decreases from left to right (see text). North is at the top of the map. The circled sites are the locations for the experimental exclusion of insects from developing buds, flowers, and seeds of Haplopappus squarrosus.

jacent habitats (Harper 1969, Stanton 1975, Meehan et al. 1977, Maiorana 1981), lead to apparent habitat restriction (Huffaker and Kennett 1959, Harper 1969), and contribute to replacement of two species along a microtopographic moisture gradient (Handel 1976). These results, plus observations of the effect of differential predation by carnivores on their prey populations (e.g., Brooks and Dodson 1965, Paine 1966, Connell 1970, 1971), suggest that seed predation also could cause both small-scale local patterns and largescale geographic patterns in plant abundance.

The data available on the impact of seed predators are suggestive but not conclusive. The common assumption, that seed loss leads to proportionate decreases in establishment (and thus to reduction in plant abundance), needs to be tested; alternative hypotheses exist (e.g., Harper 1977, Louda 1982). Some plants, for example, compensate for early losses by further reproductive effort (e.g., Janzen 1971b). Alternately, some plant populations are limited at later stages in their life histories. Harper et al. (1965) and others (Harper 1977: Chapter 5) have demonstrated that the availability of germination sites, rather than supply of viable seeds, can limit seedling establishment and population recruitment. Therefore, the assessment of seed predation effect on plant dynamics requires a test of the relation between seed production and plant recruitment. This test should quantify recruitment when native predators are experimentally excluded: (1) within a local population (Louda 1978, 1982), and (2) over the environmental range of the insect-plant interaction (Janzen 1975a, b, Louda 1978, Hare and Futuyma 1978).

The observations and field experiment reported here were designed to test the numerical and spatial consequences of flower and seed consumption by insects for a native plant, Haplopappus squarrosus H. \& A., over an environmental gradient. My specific aim was to test the hypothesis that predispersal seed predation limits seedling establishment and juvenile recruitment of a native shrub differentially along a climatic gradient.

If seed predation is critical in the pattern of $H$. squarrosus abundance along the gradient, four predictions can be made: (1) plant abundance should be inversely related to predation intensity; (2) plant abundance should be correlated with the number of viable seeds after predation rather than with the number of flowers initiated or pollinated; (3) seedling establishment should be directly proportional to the number of undamaged viable seeds; and (4) juvenile recruitment after $1 \mathrm{yr}$ should be directly proportional to the number of viable seeds released. So, if predispersal seed predation limits abundance, then an experimental reduction in the number of seeds destroyed must increase: (1) viable seeds released, (2) seedlings established, and (3) juveniles recruited. Also, if seed predation restricts distribution in a portion of the gradient, the experimental increase must be greatest in the area of the plants' least abundance. Adult mortality, finally, must not be greatest where plant density is lowest. If the alternative hypothesis is true, that seedling establishment, juvenile recruitment, or adult plant occurrence are limited by other factors, then the number of seedlings, juveniles, and adults observed will not be closely correlated with seed production after predation, both within a site and among sites along the gradient.

\section{EXPERIMENTAL SYSTEM}

\section{The study areas}

I conducted this study in San Diego County, California, USA, a region characterized by a Mediterranean climate with cool, moist winters and hot, dry summers (Barbour and Major 1977, Miller et al. 1977). Rainfall and temperature extremes increase, and average annual temperatures decrease, as one moves inland and up to the crest of the Peninsular Range that parallels the coast $(80 \mathrm{~km}$ inland). This region is divided into "areaclimates" (Close et al. 1970) which correspond to plant growing zones (Fig. 1) by integrating annual patterns in temperature and moisture (Gilbert 1970).

The maritime zone (I), adjacent to the ocean in the coastal plains, is dominated continuously by maritime air. Diurnal and seasonal changes in temperature are minimal and humidities are high all year. Summer fog is characteristic. The experimental site in this zone was at the junction of Interstate Highway 5 and Del Mar Heights Road, $22.8 \mathrm{~km}$ northwest of the city of San Diego. This site was burned in November 1969. 
The coastal zone (II) is a belt of coastal bluffs, mesas, and valleys, $17-50 \mathrm{~km}$ wide, interior to the maritime zone. Continental influence increases but the maritime air mass predominates $75-85 \%$ of the time (Gilbert 1970). Temperature fluctuations increase but humidity remains high. Summer fog is still important. The site for this zone was located in a disturbed arroyo on Interstate Highway 15 in Murphy Canyon, $3.9 \mathrm{~km}$ north of the San Diego River. The disturbance was 5$10 \mathrm{yr}$ old bulldozed grading. This site was destroyed by further bulldozing late in November 1976 .

The transition zone (III) includes the central valley and foothill areas. This area experiences either alternation of maritime and continental air or continuous intermediate conditions. Temperature variation and extremes are greater. Fog is no longer a major factor but orographic precipitation increases. The site for this zone was along the Sequan Truck Trail, $4.8 \mathrm{~km}$ south of Alpine, in the Cleveland National Forest. Both this site and the most inland site were burned in September 1970, as part of the 28000 -ha Laguna Mountain Fire.

The interior zone (IV) of foothills, valleys and mountains is dominated by continental air $75-85 \%$ of the time. Diurnal and seasonal variations in temperature and humidity are high and extremes are great. Frost occurs regularly. My zone IV site was at the junction of the Laguna Mountain Highway and Interstate Highway 8, $1.6 \mathrm{~km}$ east of Pine Valley. This site represents the highest and most eastern location of Haplopappus squarrosus observed in San Diego County.

The vegetation cover at the experimental sites is primarily coastal sage scrub. The main shrubs for all sites were: $H$. squarrosus, Adenostoma fasciculatum, Quercus dumosa, Ceanothus spp., Arctostaphylos spp., Lotus scoparius and Eriogonum fasciculatum (Table 1, nomenclature of Munz and Keck 1970).

\section{The plant}

Haplopappus squarrosus subsp. grindelioides is characteristic of the coastal scrub (Mooney 1977) and occurs from northern Santa Barbara County to central Baja California, growing on granite rock, sand, clay, and silt soils (Hall 1928, and S. M. Louda, personal observation). It is a small $(0.3-1.0 \mathrm{~m})$, loosely branched shrub, which occurs in disturbed areas such as burns (Vogl and Schorr 1972, Hanes 1977), arroyo walls, and roadcuts; $H$. squarrosus occurs as isolated individuals or in small $\left(10-\mathrm{m}^{2}\right)$ stands. The plants are most frequent on north- or west-facing slopes.

Vegetative growth occurs in the winter and spring. Sexual reproduction begins in early summer with initiation of flower heads. Plants flower from August to September. There is a high degree of reliance on outcrossing for viable seed (S. M. Louda, personal observation). The most frequently observed flower visitors are: Apis mellifera and Bombus spp. (Apidae) and a sweat bee (Halictidae). The single-seeded fruit, an
TABLE 1. Cover of shrubs and herbs at main study sites.* Dash indicates species not present.

\begin{tabular}{lcccc}
\hline & \multicolumn{5}{c}{ Percent cover } \\
\cline { 2 - 6 } & Zone & Zone & Zone & Zone \\
& 1 & 11 1 & III & IV \\
\hline Shrub species & & & & \\
$\quad$ Haplopappus squarrosus & 5.8 & $\mathrm{p}$ & 7.9 & 8.8 \\
Adenostoma fasciculatum & 13.8 & $\mathrm{p}$ & 14.7 & 11.3 \\
Quercus dumosa & 6.8 & $\mathrm{p}$ & 3.5 & 17.7 \\
Ceanothus greggii & - & - & $\mathrm{p}$ & 6.0 \\
Ceanothus leucodermis & - & - & - & 0.5 \\
Ceanothus tomentosus & 3.2 & $\mathrm{p}$ & 15.6 & - \\
Ceanothus verrucosus & 6.0 & - & - & - \\
Helianthemum scoparium & 10.7 & $\mathrm{p}$ & 2.7 & - \\
Cercocarpus betuloides & - & - & - & 5.4 \\
Lotus scoparius & 4.2 & $\mathrm{p}$ & 0.4 & $\mathrm{p}$ \\
Eriogonum fasciculatum & $\mathrm{p}$ & $\mathrm{p}$ & 0.1 & 3.6 \\
Arctostaphylos glandulosa & 3.5 & $\mathrm{p}$ & - & - \\
Other shrubs & 3.6 & $\mathrm{p}$ & 4.0 & 4.8 \\
Total shrubs & 57.6 & & 48.9 & 58.1 \\
Total herbs & 3.5 & & 1.8 & 1.7 \\
No cover & 38.9 & & 49.3 & 40.2 \\
\hline
\end{tabular}

* Percent cover taken to nearest centimetre; $N=120 \mathrm{~m}$ per site.

$\dagger$ Plant names follow Munz and Keck (1970).

\$ Main site in zone II was bulldozed before cover data taken; $p$ indicates field notes show plant was present.

achene, is released from late October to mid-November. Seedlings establish in January and February. $H$. squarrosus increases to a limited extent by rhizomes.

\section{The seed predators}

The predispersal insect seed predators include flies, microlepidopterans, seed chalcids, and thrips. Their parasitoids and hyperparasitoids are also found in the flower heads. Mites (Acarina) also occur and may be phytophagous.

Diptera.-The flies are typical Tephritidae (Trypetidae), subfamily Tephritinae. Most species in this subfamily develop on the seeds of composites (Christianson and Foote 1960). Eggs are inserted into small (3-5 mm) flower heads or into newly exserted corollas. The larvae grow and compact seeds within the head as they grow; no gall is formed. Early oviposition causes abortion of flower heads; with later oviposition, heads continue to grow prior to complete disruption by the developing larvae. The smaller the flower head at the time of oviposition, the greater the seed damage by a developing fly. The adults reared from pupae in the flower heads $(N=55)$ include: Trupanea wheeleri Curran (76.4\%), Urophora formosa (21.8\%) and Neospilota signifera (Coquillet).

Lepidoptera._-All of the moths using the developing flowers and seeds are microlepidoptera: Tortricidae, Gelechiidae, Cochylidae (Phaloniidae) and Pterophoridae. Two types of information are available: (1) identifications of adults reared, and (2) relative frequency of larval forms in the flower heads (Louda 1978). Three forms, in three families, make up the majority $(78.7 \%)$ 


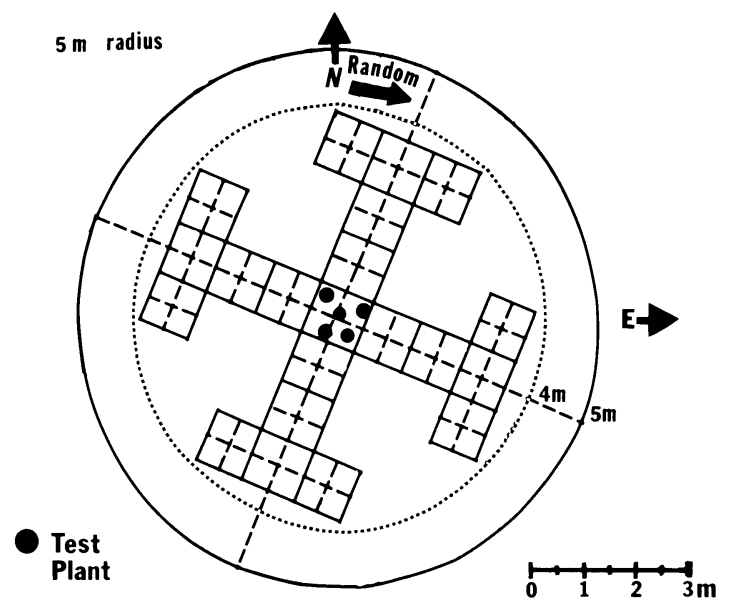

FIG. 2. Diagram of a randomly oriented experimental plot with quadrats for seedling establishment. Two replicate plots ( $5 \mathrm{~m}$ radius) for each of the three treatments were established at each of the four experimental sites along the climatic gradient from coast to mountains. Each seedling quadrat is a 1 $\mathrm{m}$ square, divided into four subsections of $50 \times 50 \mathrm{~cm}$.

of moth larvae found (Louda 1978). Two are considered to be specialized feeders: the gelechiid, Sophronia sp. (R. W. Hodges to J. A. Powell, personal communication), and the cochylid species (J. Clark to J. A. Powell, personal communication). These make up $57.4 \%$ of the larval material from $H$. squarrosus. The third is the tortricid, Clepsis peritana (Clements), a generalized feeder (Powell 1964:286), composing $21.3 \%$ of the larvae collected $(N=235)$.

Hymenoptera. - The hymenopterans in the heads of $H$. squarrosus include seed predators and parasitoids. The seed predators are pteromalids; one causes urnshaped galls on individual seeds and another mines multiple seeds. The tephritid flies have pteromalid (80.4\%) and eurytomid (19.6\%) pupal parasitoids $(N=$ 46). In addition, eupelmids $(N=10)$ were also reared from a fly pupa. Three parasitoids are associated with moth larvae: a braconid, an ichneumonid and a proctotrupid.

Thysanoptera.-Thrips occur on $H$. squarrosus flowers. I found identifiable adults of the following: Frankliniella occidentialis (12), F. minuta (4), and one individual of an unidentified species of Haplothrips (W. H. Ewart, personal communication). These genera are phytophagous and flower feeders (Lewis 1973).

\section{Methods}

\section{Geographic patterns}

Frequency and density.-Observations on the distribution of Haplopappus squarrosus within rural San Diego County were made by recording presence or absence along roadsides. I traversed the county, allocating effort among zones in proportion to their area. The sampling units were $170 \mathrm{~m}$ long $(0.1 \mathrm{mile})$ and 20
$25 \mathrm{~m}$ wide. The total number of these 0.3-0.4 ha units equalled 15 250: 2250 in zone I; 3950 in zone II; 5050 in zone III; and 4000 in zone IV (Fig. 1).

The product of plant density and frequency of occurrence provided an estimate of relative abundance in each zone. I recorded the density of plants at sites from which samples were collected. I define an individual plant to be a clump of stems at least $25 \mathrm{~cm}$ away from the next nearest stem. To estimate density, I recorded individuals on two parallel transects $(\bar{x}=30$ m) of $2 \times 2$ m quadrats at each sampling site.

Sample collection and sorting.-Samples for estimation of seed production and destruction were collected at sites which were $8-16 \mathrm{~km}$ apart throughout the county and near the margins of distribution (Fig. 1). Each sample consisted of five or more racemes taken from a random quadrant of a plant, from up to 15 randomly chosen individuals at a site. Samples were stored until sorted (Louda 1978). Other data collected at each site include: number of racemes per plant $(N=25)$, distance to nearest neighbor $(N=$ 25 ), elevation, slope, and aspect.

In processing the samples, I recorded the total number of flower heads and the number of damaged heads per raceme as well as the number of initiated, set, viable, and damaged seeds per head. Since the achene is a single-seeded fruit, I use seed to refer to all stages of its development. I also recorded the type of damage and the insects present. Three different statistical methods yielded the same minimum required sample sizes (Sokal and Rohlf 1969:246) for the nonparametric tests to be used (Louda 1978): 10 large, empty heads; 25 large heads, filled with seeds; and 10 small, undeveloped heads.

\section{Experimental exclusion}

Establishment of plots.-There were six plots at each site, two plots for each of three treatments arranged in two replicate blocks. I established each block of three plots in a homogeneous subsection of each main site. A plot was a circle of $5 \mathrm{~m}$ radius with five experimental plants located in the central square metre (Fig. 2). I measured the plants and then pruned them by removing basal stems chosen randomly. Each group of five plants then consisted of 190 branches at all sites except in one block at Sequan Truck Trail site (III) which had only 150 branches per plot. Immature inflorescences on all other $H$. squarrosus individuals within the plots were removed to prevent seed set by nonexperimental plants.

Finally, existing seedlings were marked and viable seeds present initially were sampled by taking 12 surface soil samples from each plot. Each sample was $25 \times 25 \mathrm{~cm}$ and $2.5 \mathrm{~cm}$ deep. These were located in concentric rings from the center of each plot: $0-1.0 \mathrm{~m}$ $(N=3), 1.0-2.5 \mathrm{~m}(N=4)$ and $2.5-4.0 \mathrm{~m}(N=5)$. Cover of plants at each site was measured by line intercept on four $25-\mathrm{m}$ transects. 
Application of treatments.-I used three treatments: (1) insecticide dissolved in water, (2) water only, and (3) nothing added. Treatments were assigned to plots randomly within blocks. The experiment began 22 July 1976, 2-3 wk after initiation of the first inflorescence buds, and continued biweekly until 15 October 1976, near the end of fruit set.

For the insecticide treatment I sprayed the central test plants with Ortho Isotox ${ }^{\circledR}$ (Chevron Chemical Company), using the recommended concentration of $6.7 \mathrm{~mL} / \mathrm{L}$ of water. This insecticide combines low phytotoxicity with some systemic action and a surface residual (M. D. Atkins, personal communication). The plants were sprayed to drip point using $1.0-1.5 \mathrm{~L} /$ plant. The second treatment was a control for the application of water solvent in the first treatment. I applied 1.0-1.5 L of water to each plant at the same biweekly interval. The third treatment was a control for both water and systemic insecticide-plus-water applications; I did nothing after the initial plot establishment.

\section{Documentation of resulting patterns}

1. Production effort and treatment effectiveness.At the end of the fruiting period I recorded the following: racemes per plant, total flower heads per raceme, unaborted heads per raceme, flowers initiated per unaborted head, seeds set per unaborted head, and viable seeds per unaborted, developed head. I recorded these in the field between 2-16 November 1976. The racemes per plant were counted. The other parameters were sampled by counting heads on two racemes per plant ( $N=10$ per plot) and by examining five unaborted heads on each of the racemes $(N=10$ heads per plant, 50 per plot).

There were three parameters for treatment effect. The first was the total number of flowers, or potential seeds, initiated per plant, the product of: racemes per plant, total heads per raceme, and flowers per head. The second was the number of set and matured seeds, whether damaged or not, per plant, the product of: racemes per plant, unaborted heads per raceme, and seeds set per head. The third parameter was the number of viable seeds, i.e., matured and undamaged seeds available for release per individual, the product of: racemes per plant, unaborted heads per raceme, and undamaged set seeds per unaborted head.

2. Seedling establishment.-Seedling quadrats were staked in each plot before seed release. From the central $1 \mathrm{~m}^{2}$, I laid out two perpendicular lines of square metres, each divided into $50 \times 50 \mathrm{~cm}$ quadrats (Fig. 2). Two metres were added adjacent to the outermost metre on all lines. The first line was at a random angle from north (Fig. 2). The quadrats censused $41.7 \%$ of the surface area of the 4-m radius inner circle.

In February 1977, the end of the main period of germination, the number of seedlings established in quadrats was counted in each plot $(N=84,50 \times 50$ cm quadrats) for treatments 1 and 2 (Fig. 2). I estimated the number of seeds required to establish a seedling by comparing $41.7 \%$ of the seeds produced to the number of seedlings established in the $41.7 \%$ of the surface area covered by quadrats.

3. Seedling survival to juvenile recruitment.-The change in the number of seedlings in marked quadrats was recorded every 3 mo from February 1977 until August 1978. The number of seedlings surviving to enter the 1-yr-old age class was defined as the number of juveniles recruited. After the first quarter, I marked seedlings and measured the height and counted the leaves per individual for 50 seedlings at each site.

4. Juvenile and adult mortality.-Significant differential mortality during later stages could modify the interpretation of population dynamics based on seed production, seedling establishment, and juvenile recruitment. Consequently, I sampled mortality of later stages at each site. I defined juveniles as small plants ( $<15 \mathrm{~cm}$ height) with no evidence of having flowered. Adults were large plants $(>20 \mathrm{~cm})$ with evidence of having flowered. I tagged up to 100 juveniles per site in the marked quadrats in February 1977, and 50 randomly chosen adults in March 1977. All sizes of adults were included. I recorded survival of these plants quarterly.

Nonoverlap of $95 \%$ confidence intervals provided a conservative visual criterion of significance (Hubbs and Perlmutter 1942, Simpson et al. 1960, Browne 1979). Nonparametic statistics were used to test differences.

\section{RESUlts}

\section{Geographic patterns}

Frequency and density of adilts.-The frequency of $H$. squarrosus increased along the gradient from ocean to mountains (Fig. 3). The most frequent occurrence of $H$. squarrosus was in the inland transition (III) zone.

Density at sampled sites was independent of climatic zone (Table 2). Consequently abundance, the product of frequency and density, had the same pattern as frequency over the gradient (Fig. 3). This distribution of plants provided the basic pattern to be explained.

Flower production. - The flowers initiated represent maximum potential seed production under present conditions. As many flowers were initiated by plants in the coastal zones, where $H$. squarrosus is infrequent, as were initiated by plants in the inland areas, where $H$. squarrosus is frequent. The rank order among zones for flowers initiated, or maximum potential seeds, was: maritime (I), coastal (II), transition (III), and interior (IV) (Table 3); however, the differences among zones were not statistically significant $(P>.05)$.

Several components of flower production varied significantly among climatic zones. The lowest numbers 


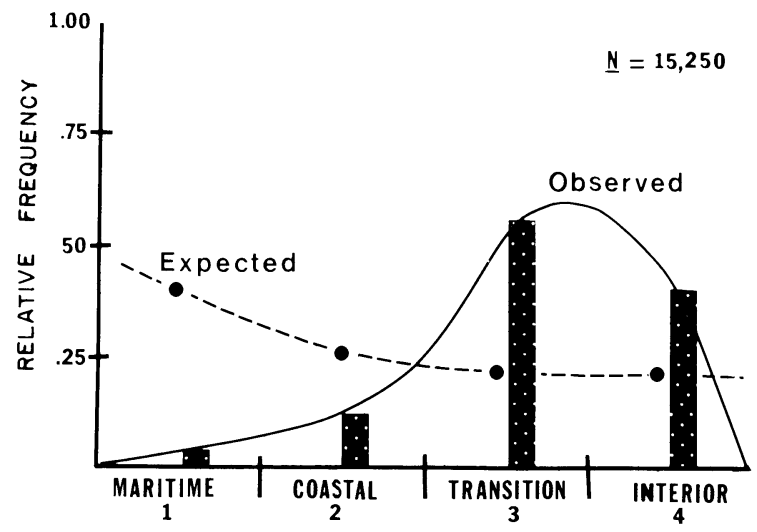

FIG. 3. Observed vs. expected relative frequency of Haplopappus squarrosus over the climatic gradient. Observed frequency is based on presence or absence of plants/ $167 \mathrm{~m}(0.1 \mathrm{mile})$ of nonurban roadside; 15250 such segments were examined. Observed frequency approximates abundance (=frequency $\times$ density) over the gradient since density does not differ significantly between zones. Expected relative frequency and abundance along the gradient based on physiological constraints are estimated by total number of flowers initiated per individual in each zone.

of branches and racemes per plant, estimates of plant size, were in the interior (IV) zone, yet the number of flower heads per raceme was greater there than it was in zones I and III (Louda 1978). Furthermore, individuals in both extreme zones had more seeds per head than did those in the intermediate zones (Louda 1978).

Seed production after predation.-Seed loss to predators was high and decreased from coast to mountains both for the geographical samples and in the experimental controls (Fig. 4). The proportion of flower heads damaged was highest in the maritime zone $(72.8 \%)$ and decreased linearly toward the transition zone (Table 3). For the geographical sample, predation changed the rank order among zones for viable seeds produced from one that paralleled flowers initiated (I $>$ II $>$ III $>$ IV) to one that was identical with adult frequency (Table 3; Kendall Rank Correlation Coefficient $=1.00, P<.05)$. There was no significant difference in the proportion of unaborted heads damaged between the geographic samples and the experimental controls (Fig. 4B); thus the experimental sites were representative of the large-scale pattern.

\section{Experimental exclusion}

Pretreatment conditions. - Neither plant size nor seed supply in the soil nor initial seedling density varied among treatments or sites. Initial plant sizes were the same at the three sites which remained throughout the study-I, III, IV (Louda 1978). Plant sizes after pruning were equal at the start of the experiment, except for the one smaller replicate at the zone III site (Louda 1978); the initial difference was not significant statistically but contributed to the variation among
TABLE 2. Density of Haplopappus squarrosus at geographical sampling sites, Fall 1975.

\begin{tabular}{lccc}
\hline & $\begin{array}{c}\text { No. of } \\
\text { sites }\end{array}$ & $\begin{array}{c}\bar{x}^{*} \\
\left(\text { no. } / \mathrm{m}^{2}\right)\end{array}$ & SE \\
\hline Zone I, maritime & 4 & 0.86 & 0.07 \\
Zone II, coastal & 4 & 0.93 & 0.08 \\
Zone III, transition & 7 & 0.95 & 0.06 \\
Zone IV, interior & 7 & 0.97 & 0.06 \\
\hline
\end{tabular}

* Kruskal-Wallis test for difference among zones, $\alpha=.05$, NS

replicates at the end. Final plant sizes, represented by the number of flowering racemes per plant (Table 4A), were similar among treatments and among sites. No viable seeds were found in the soil at any site. Only two seedlings were found initially; both were in zone I.

Flower production.-Flower initiation was greatest at the coast, where $H$. squarrosus was least abundant. The number of flowers initiated per plant, or maximum potential seeds under present conditions, decreased from zones I through IV. These results paralleled the geographical data (Table 3). Flower initiation at the maritime (I) site was significantly greater than that at the next most inland site (II) and both of these were greater than flower initiation at the two inland (III, IV) sites (Table 5B). Plants sprayed with pesticide in water, with water only, or with nothing, did not differ in flower initiation (Table 5B).

Three components of flower production were significantly higher in the coastal zones. (1) Flowering racemes per plant were greatest in zone I (Table 4A). (2) Total heads per raceme were significantly greater for plants at the two coastal (I, II) sites than for plants at the two inland (III, IV) sites (Table 4B). The number of heads per raceme did not vary among treatments at any site (Table 4B). (3) The number of flowers initiated per flower head was greater at the maritime (I) site than at the other three sites; no significant difference occurred between treatments (Table 4C). So the combination of a greater number of racemes (I), a higher number of heads per raceme (I and II), and more potential seeds per head (I) determined the I $>$ II $>$ III $>$ IV ranking among zones for flowers, or potential seeds, initiated (Table 5B).

Seed production after predation.-The pesticide was effective in decreasing damage by chewing insects (Table 5B, $P<.02$ ). The number of undamaged seeds released by insecticide-sprayed plants was increased significantly over control plants at all sites (Table 5B). The increase in undamaged set seeds involved: (a) decreased abortion of flower heads, and (b) decreased destruction of seeds. The production of viable seeds was increased to a similar level at sites I, II, and IV; however, release of viable seed was low at the site (III) that had the one replicate composed of smaller shrubs.

The reduction in the proportion of seeds damaged 
A. All Heads

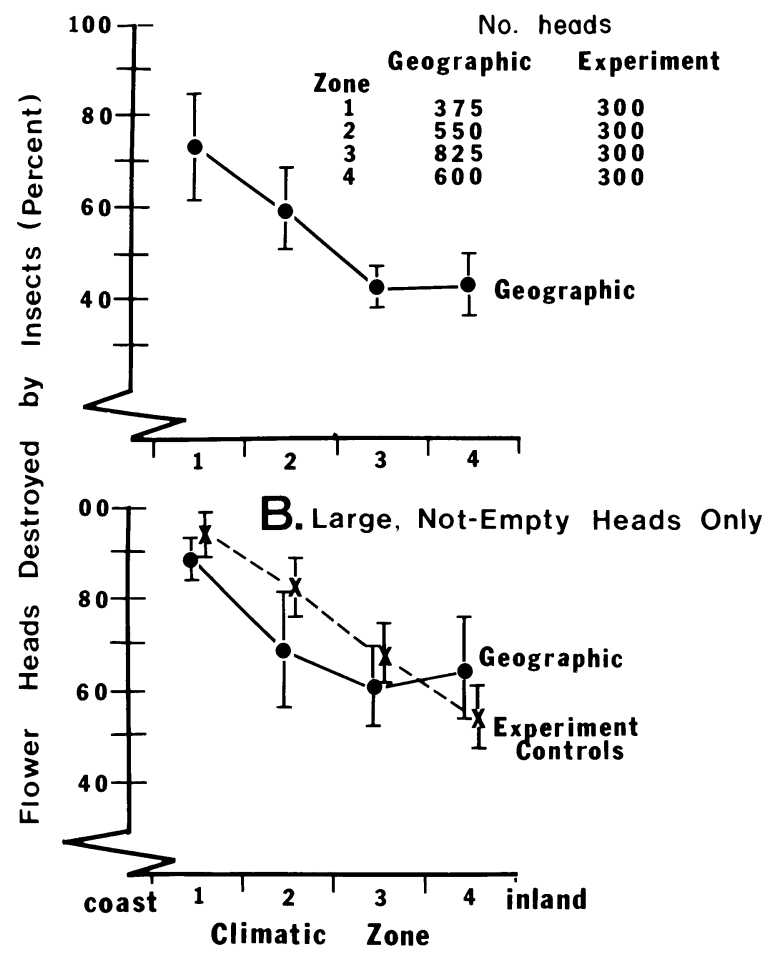

FIG. 4. Pattern along the gradient in damage to flower heads by insects for both geographic samples and experimental controls, November 1976. Damage is expressed as mean percent for all classes of flower heads (A) and for large, nonempty heads only (B). Means and $95 \% \mathrm{Cl}$ shown were calculated on arcsine-transformed data; values displayed have been back-transformed. Chi-square one-sample tests of difference between sites on arcsine-transformed proportions over the gradient are significant $(P<.001)$. In $\mathrm{A}, \mathrm{I}>\mathrm{II}>$ III and IV, and in B, I > III and IV, for experimental controls and I > II, III and IV for geographic data by the Student-Newman-Keuls procedure (Sokal and Rolhf 1969). However, over the gradient the geographic and experimental data do not differ significantly from each other (StudentNewman-Keuls test).

following application of insecticide was least at the maritime (I) site (Table 5A). Two factors contributed: (1) this site had the highest losses overall (Table 5A), and (2) since plant development here was ahead of inland sites (S. M. Louda, personal observation), more bud development and head abortion had occurred by the time the experimental exclusion was started. On unmanipulated controls, the zones decreased in rank from IV to I in the number of viable seeds after predation, compared to a IV, II, I ordering among zones for the pesticide treatment. Seed predation, then, changed the order among zones from one parallel to flower initiation (Table $5 \mathrm{~B}$ ) to one more similar to observed adult occurrence (Fig. 3).

Application of insecticide did not interfere with seed set, either per flower head (Table 4B) or per plant (Table 5B). These did not vary among treatments. The increase in viable seeds per plant resulted from both decreased early damage to heads (Table 4B) and decreased later damage to set seeds (Table $4 \mathrm{C}$ ). The proportion pollinated, however, was higher at the interior site $(56.3 \%)$ than at the other sites (I, 31.8\%; II, 27.4\%; III, 29.8\%: Table 4C).

Seedling establishment.-The experimental decrease in predispersal seed predation led to an increase in seedling establishment. The increase was greatest at the coast. The number of seedlings established per plant in the pesticide exclusion treatment increased at all sites (Table 6A). In the smaller replicate at the Sequan Truck Trail site (III), both pesticide and wateronly plots produced few seeds and recruited few seedlings. On pesticide plots more seedlings were established per plant at the coast (zone I) than inland (Table 6C). On control plots, however, more seedlings were established at the transition zone (III) site than elsewhere (Fig. 5).

The number of flowers initiated for each seedling established was significantly lower on the exclusion treatment in each zone: by a factor of 20 in zone I, 6 in zone III and 6 in zone IV (Table 6B). The number of seeds set required for each seedling established also decreased significantly (Table 6B). Much higher flower initiation and pollination were required to establish a seedling when insects were present. The pesticide did not change germinability since it did not increase the number of viable seeds needed for each seedling established within any site (Table 6B). Between sites, however, the number of seedlings established for each

TABLE 3. Maximum seed production effort and adult plant occurrence along the climatic gradient. Maximum potential seed production defined as total number of flowers initiated per plant.

\begin{tabular}{|c|c|c|c|c|c|c|}
\hline & \multicolumn{2}{|c|}{$\begin{array}{l}\text { Total flowers initiated } \\
\text { per plant }\end{array}$} & \multicolumn{3}{|c|}{$\begin{array}{l}\text { Undamaged, set } \\
\text { seeds per plant }\end{array}$} & \multirow{2}{*}{$\begin{array}{l}\text { Adult plant } \\
\text { frequency* } \\
\frac{\text { Rank }}{}\end{array}$} \\
\hline & Number & Rank & $\%$ & Number & Rank & \\
\hline Zone I, maritime & 15735 & 1 & 27.2 & 4280 & 4 & 4 \\
\hline Zone II, coastal & 12795 & 2 & 40.1 & 5130 & 3 & 3 \\
\hline Zone III, transition & 11305 & 3 & 56.4 & 6375 & 1 & 1 \\
\hline Zone IV, interior & 11150 & 4 & 55.8 & 6220 & 2 & 2 \\
\hline
\end{tabular}

* Adult plant frequency vs. total number of flowers initiated, Kendall Rank Correlation Coefficient $=-0.67$, NS; adult plant frequency vs. postpredation number of undamaged, set seeds, Kendall Correlation Coefficient $=1.0, P<.05$. 
TABLE 4. Components of plant performance over the gradient in the experiment. $\dagger$

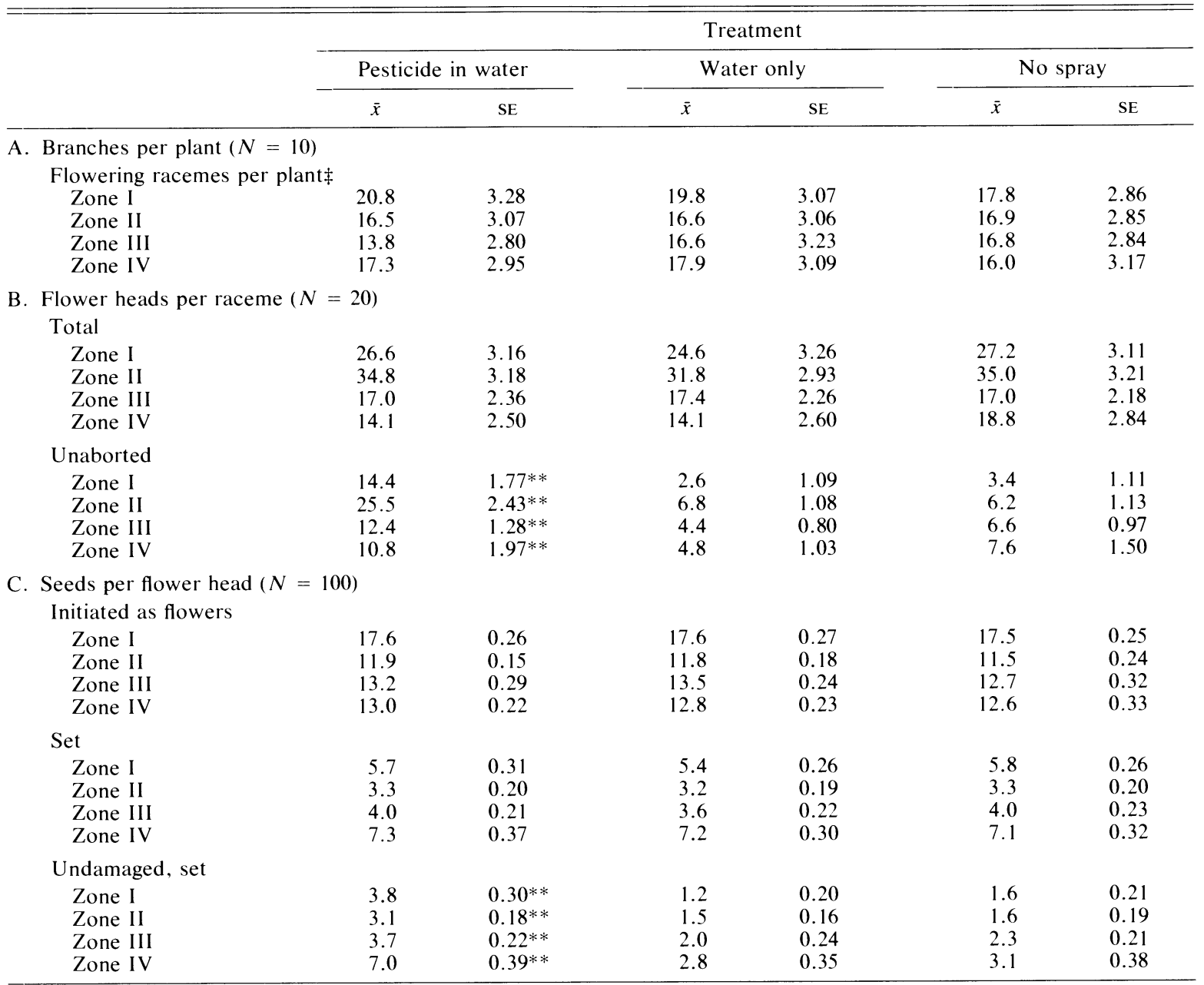

$\dagger N=$ number per treatment per site. Comparison of controls within each site, $P>.05$, Ns in all cases; pesticide vs. water control; $* *=P<.01$ in all zones (Wilcoxon Two-sample Test in both cases).

$\ddagger$ Number of flowering racemes equals number of flowering branches per plant.

viable seed released was much lower in the interior than elsewhere (Table 6B). The postdispersal environment, thus, was harsher at the interior site.

Removal of predispersal seed predators increased the density of seedlings established around the parent group (Fig. 5). This increase was significant at all distances at all sites except the farthest distance at the most interior site. Predation, however, did not change the basic shape of the seedling distribution.

Seedling survival. - The experimental decrease in seed predation increased the number of juveniles recruited, and the increase was greatest at the coast (Table $6 \mathrm{C}$ ). A higher number, and a higher proportion, of seedlings survived at the coast than at the inland sites in pesticide plots (Table 6C). At $1 \mathrm{yr}, 96.0 \%$ of all $H$. squarrosus seedlings surviving were in the pesticide-sprayed plots $(N=25)$. Furthermore, of the 25 seedlings surviving, 24 were at the coast (I); the 1 seedling surviving inland was in a pesticide plot. The average survival rate for all seedlings of $H$. squarrosus was $3.86 \%(N=647)$. The rate was much higher at the maritime (I) area $(6.9 \%, N=345)$ than at the transition $(0.44 \%, N=227)$ or interior $(0.01 \%, N=75)$ areas.

Survivorship patterns differed significantly among zones but not between treatments within zones (Fig. 6). Thus the pesticide did not affect seedling viability. Survival during the spring was significantly higher at the interior (IV) site than at the other two sites, but survival over the year was significantly higher at the coast (I) than elsewhere (Fig. 6). In fact, at $1 \mathrm{yr}$, survival was 16 times higher at the maritime (I) site than at the transition (III) site. Since winter precipitation was greater and soil moisture lasted longer in the interior, and since fog was restricted to the coastal areas (Louda 1978), the survival patterns of $H$. squarrosus 
TABLE 5. Insect damage and seed production over the gradient in the experiment.

\begin{tabular}{|c|c|c|c|c|c|c|c|}
\hline & \multicolumn{6}{|c|}{ Treatment $\dagger$} & \multirow[b]{3}{*}{$P \ddagger$} \\
\hline & \multicolumn{2}{|c|}{$\begin{array}{l}\text { Pesticide } \\
\text { in water }\end{array}$} & \multicolumn{2}{|c|}{ Water only } & \multicolumn{2}{|c|}{ Nothing added } & \\
\hline & $\bar{x}$ & $\mathrm{SE}$ & $\bar{x}$ & $\mathrm{SE}$ & $\bar{x}$ & SE & \\
\hline \multicolumn{8}{|c|}{ A. Insect damage $(\%) \S$} \\
\hline Zone I & 43.6 & $0.32 * * *$ & 91.4 & 0.31 & 91.3 & 0.29 & \\
\hline Zone II & 4.8 & $0.39 * * *$ & 77.1 & 0.67 & 78.8 & 0.48 & \\
\hline Zone III & 15.5 & $1.04 * * *$ & 68.2 & 0.10 & 70.0 & 0.26 & \\
\hline Zone IV & 3.0 & $0.35^{* * *}$ & 52.3 & 0.21 & 51.2 & 0.25 & \\
\hline All & 12.4 & 2.39 & 72.8 & 3.72 & 75.5 & $\overline{3.36 * * *}$ & \\
\hline \multirow{2}{*}{\multicolumn{8}{|c|}{$\begin{array}{l}\text { B. Seeds per plant } \\
\text { Initiated }\end{array}$}} \\
\hline & & & & & & & \\
\hline Zone I & 9494 & 952 & 8222 & 178 & 8767 & 3060 & \\
\hline Zone II & 6797 & 782 & 6236 & 1256 & 6846 & 1024 & \\
\hline Zone III & 3184 & 1180 & 3714 & 297 & 3645 & 382 & \\
\hline Zone IV & 3292 & 1332 & 3097 & 21 & 3584 & 254 & \\
\hline All & $\overline{5692}$ & 1076 & $\overline{5318}$ & 812 & $\overline{5710}$ & 1036 & NS \\
\hline \multicolumn{8}{|l|}{ Set } \\
\hline Zone I & 3102 & 238 & 2553 & 39 & 2912 & 1120 & \\
\hline Zone II & 1851 & 175 & 1655 & 250 & 1860 & 282 & \\
\hline Zone III & 971 & 348 & 1011 & 134 & 1150 & 171 & \\
\hline Zone IV & 1822 & 648 & 1722 & 111 & 2032 & 208 & \\
\hline All & 1936 & 324 & 1735 & 215 & 1989 & 326 & NS \\
\hline \multicolumn{8}{|c|}{ Undamaged, set } \\
\hline Zone I & 1195 & $509 * * *$ & 60 & 22 & 87 & 15 & \\
\hline Zone II & 1314 & $152 * * *$ & 166 & 18 & 186 & 78 & \\
\hline Zone III & 662 & $288^{* *}$ & 139 & 1 & 264 & 104 & \\
\hline Zone IV & 1325 & $542 * * *$ & 218 & 14 & 350 & 80 & \\
\hline All & 1124 & 185 & 146 & 22 & 212 & 47 & $* *$ \\
\hline
\end{tabular}

† Comparison of controls within each site: $P>.05$, NS in all cases; comparison of pesticide to water control: $* *=P<.01$, $* * *=P<.001$ (Wilcoxon Two-sample Tests).

\$ Kruskal-Wallis Test for differences among all three treatments, all sites.

$\S$ Test done on arcsine-transformed proportions.

seedlings were probably related to moisture availability.

Density-dependent regulation of seedling establishment or survivorship was not detected. The number of seedlings surviving was proportional to the number established and the probability of recruiting a juvenile increased as establishment density of seedlings increased (Table 7). Seedling densities on pesticide plots were initially high, but mortality over the $1 \mathrm{st}$ yr was high, $96.1 \%$, and independent of initial seedling density (Table 7). At Del Mar Heights (I), for example, juveniles were recruited in quadrats which initially ranged from 4 to 108 seedlings. The quadrats with at least one survivor had a higher initial density of seedlings $(6.9, \mathrm{SE}=0.42, N=15)$ than did quadrats with no survivors $(3.0, \mathrm{SE}=0.09, N=82)$.

Adult density, in addition, did not limit juvenile recruitment. Adult densities and total plant cover did not differ significantly among sites (Louda 1978). The density of seedlings surviving, even on the pesticide plots, was less than observed adult densities. The density of plants at $1 \mathrm{yr}$ on all experimental plots in all zones was below the density observed in established stands (Table 8). Even the highest density of juveniles recruited in the experiment was still only two-thirds of the mean adult density for each zone and well below high-density situations observed (Table 8 ).

The type of mortality suffered by seedlings was similar among the sites. Physical disappearance of seedlings was greater than the proportion that dried and remained in situ, especially in the interior (IV) (Table 9). In addition, seedlings planted in openly accessible, partial cages in March 1975, disappeared more rapidly but not as completely at the coast (I) than at the transition site (III). By March 1976, one out of 12 partially caged seedlings remained at the coast (I) whereas none remained in these open cages at the zone III site. I found rabbit pellets in the open cages; seedling predation by rabbits, therefore, may explain these patterns. Apparent desiccation of seedlings was high but generally similar between sites (Table 9).

Juvenile and adult mortality.-Survival of established juveniles and adults was similar at all sites over the gradient; the highest rate of survival was at the coast (Table 10). This trend of equal or lower mortality in the maritime (I) area reinforced the pattern in the 
TABLE 6. Seedling establishment and juvenile recruitment in the experiment.*

\begin{tabular}{|c|c|c|c|c|c|}
\hline & \multicolumn{4}{|c|}{ Treatment } & \multirow[b]{3}{*}{$P \dagger$} \\
\hline & \multicolumn{2}{|c|}{ Pesticide in water } & \multicolumn{2}{|c|}{ Water only } & \\
\hline & $\bar{x}$ & SE & $\bar{x}$ & $\mathrm{SE}$ & \\
\hline \multicolumn{6}{|c|}{ A. Seedlings established per plant } \\
\hline Zone I & 35.5 & 7.50 & 1.5 & 0.50 & .001 \\
\hline Zone III & 19.5 & 11.50 & 3.5 & 0.50 & .001 \\
\hline Zone IV & 6.5 & 2.50 & 1.0 & 0.00 & .05 \\
\hline All zones & 20.0 & 6.41 & 2.0 & 0.52 & .01 \\
\hline \multirow{2}{*}{\multicolumn{6}{|c|}{$\begin{array}{l}\text { B. Seeds required per seedling } \neq \\
\text { Initiated }\end{array}$}} \\
\hline & & & & & \\
\hline Zone I & 59 & 8.0 & 1196 & 145.5 & .001 \\
\hline Zone III & 40 & 12.5 & 234 & 11.5 & .001 \\
\hline Zone IV & 100 & 2.5 & 568 & 55.0 & .001 \\
\hline All zones & 67 & 11.9 & 666 & 182.8 & .01 \\
\hline \multicolumn{6}{|l|}{ Set } \\
\hline Zone I & 19 & 3.0 & 372 & 47.5 & .001 \\
\hline Zone III & 12 & 4.0 & 64 & 0.5 & .001 \\
\hline Zone IV & 57 & 2.0 & 318 & 49.5 & .001 \\
\hline All zones & 29 & 9.0 & 251 & 62.6 & .01 \\
\hline \multicolumn{6}{|l|}{ Undamaged, set } \\
\hline Zone I & 6 & 1.5 & 8 & 0.5 & NS \\
\hline Zone III & 8 & 1.5 & 8 & 0.2 & NS \\
\hline Zone IV & 40 & 1.5 & 53 & 12.0 & NS \\
\hline All zones & 18 & 7.1 & 23 & 10.0 & NS \\
\hline \multicolumn{6}{|c|}{ C. Juveniles recruited per plant } \\
\hline Zone I & 2.3 & 0.50 & 0.1 & 0.10 & .05 \\
\hline Zone III & 0.1 & 0.10 & 0 & 0.00 & NS \\
\hline Zone IV & 0 & 0.00 & 0 & 0.00 & NS \\
\hline All zones & 0.8 & 0.49 & 0.03 & 0.03 & .05 \\
\hline
\end{tabular}

* Zone II was bulldozed in the middle of the experiment.

† Wilcoxon Two-sample Test.

$\$$ Seed stages are: initiated $=$ total number of florets per plant; set $=$ total number pollinated and matured, whether damaged by insects or not; undamaged, set $=$ total number of viable seeds after predation.

experimental data, such as: plant size (Table 4A), flowers initiated (Table 5B), heads per raceme (Table 4B), flowers per head (Table 4C), seeds set per head (Table 4C), seedlings established (Table 6A), and juveniles recruited (Table 6C). H. squarrosus adults were larger, reproduced better, and survived longer in the maritime zone where the plant was relatively rare, than they did in the inland zones, where H. squarrosus was much more common (Fig. 7). Seed mortality thus appears more critical than later stage mortality in explaining recruitment and distribution of $H$. squarrosus over the climatic gradient.

\section{Discussion}

Mechanism determining plant distribution.-Haplopappus squarrosus occurred predominantly inland; both frequency of occurrence and plant abundance were lowest in the two coastal zones (Fig. 3). Three direct mechanisms could maintain this type of distributional pattern over the gradient: (1) change in physical factors, (2) variation in competitive pressure, and (3) differential intensity in predation.
1. Physical factors. - The first hypothesis is that the occurrence of $H$. squarrosus reflected the variation in physical parameters between climatic zones. If this were the explanation for the pattern, the plants in the zones where abundance was low would be expected to perform poorly compared to those where abundance was higher, with or without seed predators. The data suggest this hypothesis must be rejected. Individual plant performance was better in the coastal zones than inland. The number of flowers (potential seeds) initiated by coastal plants was as high as that initiated by inland plants (Table 5B). When seed predators were excluded, seedling establishment (Table 6A), seedling survivorship (Fig. 6D), and juvenile recruitment (Table 6C) were all higher at the coast. Juvenile and adult survivorship were as high in the coastal zone as in the inland zones (Table 10). Yet $H$. squarrosus was least abundant in the coastal zone.

2. Competition.-An alternate hypothesis is that differential competitive pressure occurs over the gradient. If competition were more intense in the coastal zones, it could eliminate $H$. squarrosus more fre- 
quently or more rapidly there than in the inland areas. Both observational and experimental data suggest a less intense, rather than more intense, competitive environment at the coast. Shrub cover did not vary significantly between the coast $(57.6 \%)$ and the most inland area $(58.1 \%$ ) (Table 1$)$. The main dominant plant species in disturbed study sites were the same over the gradient (Louda 1978). Density of H. squarrosus was uniform at sites over the gradient (Table 2). The number of viable seeds required to establish a seedling was greater inland rather than at the coast (Table 6B). Seedling survivorship was independent of seedling density (Table 7). In no case were subsequent juvenile densities of $\boldsymbol{H}$. squarrosus excessive (Table 8). These data suggest interaction among seedlings was small. Seedling (Fig. 6), juvenile (Table 10), and adult (Table 10) survivorship were all at least as high in the coastal area as elsewhere. In addition, the exclusion of seed predators caused the highest response in recruitment for coastal plants (Fig. 7B). Thus, both interspecific and intraspecific competition seem unlikely explanations for the pattern of $H$. squarrosus occurrence along the gradient.

3. Predation. - The third hypothesis involves differential predation over the gradient. Was the plant's observed abundance related to predispersal seed predation? Both the variation in seed loss between zones and the recruitment response to predator exclusion suggest that predation was important. Over the geographical scale, attack by insects on the developing flower heads varied inversely with plant occurrence (Figs. 3, 4). Absolute, and proportionate, loss to insects was greater at the coast, where plants were infrequent, than in either inland zone, where plants were more frequent. This pattern was consistent over $3 \mathrm{yr}$ (S. M. Louda, personal observation).

In the experiment the two control treatments contrasted sharply with the exclusion treatment. Predation on developing heads decreased the number of viable seeds matured (Table 5A), increasing the flower production required for each seedling established (Table 6B). Predation caused a proportionate decrease in: the number of seedlings established (Table 6A), the density of the seedling shadow (Fig. 5), and the number of seedlings surviving to the juvenile stage (Table 6C). Thus, insect flower- and seed-predators reduced H. squarrosus recruitment significantly and to below adult mean and maximum observed densities (Table 8 ) during the experiment. The greatest reduction was at the coast (Table 5B). Harper (1977: Chapter 15) emphasized that: "Predation is relevant in the control of population size if it carries the seed density below that to which the plant population will be reduced by later density-dependent processes." The data suggest that this was the case here. Juvenile and adult plant survivorship reinforced the spatial pattern established in the experiment (Table 10).

Variation along the gradient.-The extent of vari-

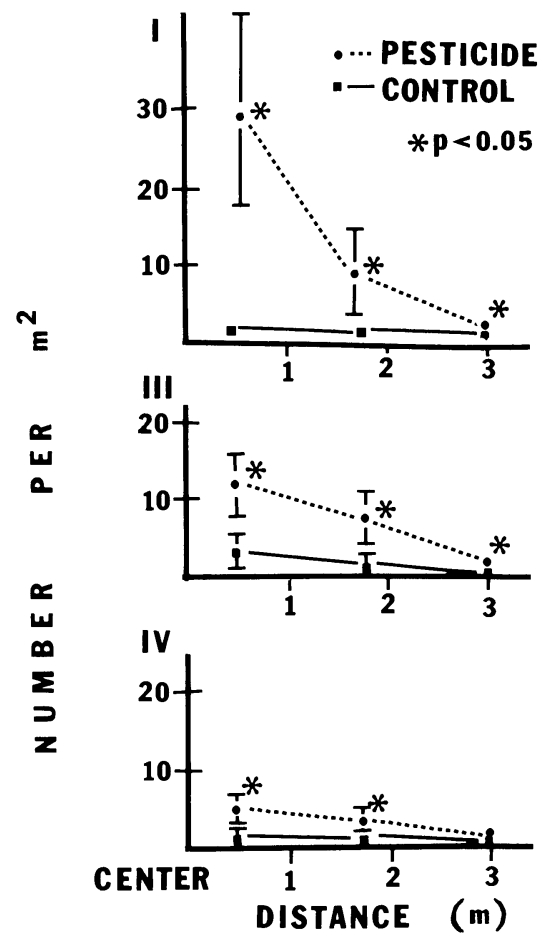

FIG. 5. Seedling shadow in the pesticide-exclusion and water-control treatments. Mean and $95 \% \mathrm{Cl}$ are presented. The average is by distance from the plot center, independent of compass direction. For each treatment at each site, $N$ equals: 24 quadrats for $0-1 \mathrm{~m}, 48$ quadrats for $1-2.5 \mathrm{~m}$, and 96 quadrats for $2.5-4 \mathrm{~m}$ radii. Each quadrat was $0.25 \mathrm{~m}^{2}$ $(50 \times 50 \mathrm{~cm})$. Differences were tested using Wilcoxon Matched-Pairs Signed Ranks test between matched plots of replicates within site.

ation along the gradient was a striking, unexpected result. Most of the components of seed production showed nonparallel trends along the gradient (Table 4). For example, all of the controls varied in the following parameters over the cline: seeds set per head (Table 4C), seedling establishment (Table 6), total seeds required to establish a seedling (Table $6 \mathrm{~B}$ ), seedling survivorship (Fig. 6), juvenile recruitment (Table 6C), juvenile survivorship (Table 10), and adult survivorship (Table 10).

1. Implications.-The outcome illustrates that a simple, observed distribution (Fig. 3) can be the result of a complex set of interacting, independently varying factors. The elevational transect is, in fact, a "complex gradient" (sensu Whittaker 1967) that is critical to the explanation of the dynamics of this plant over its distributional range. The variation suggests one explanation for divergent views of the significance of phytophagous or seed-feeding insects in plant dynamics (e.g., Dethier 1970, Janzen 1970, Connell 1971). Without experimental perturbation over the range of interaction, it is difficult to separate and rank the relative contribution of various factors to the natality and 

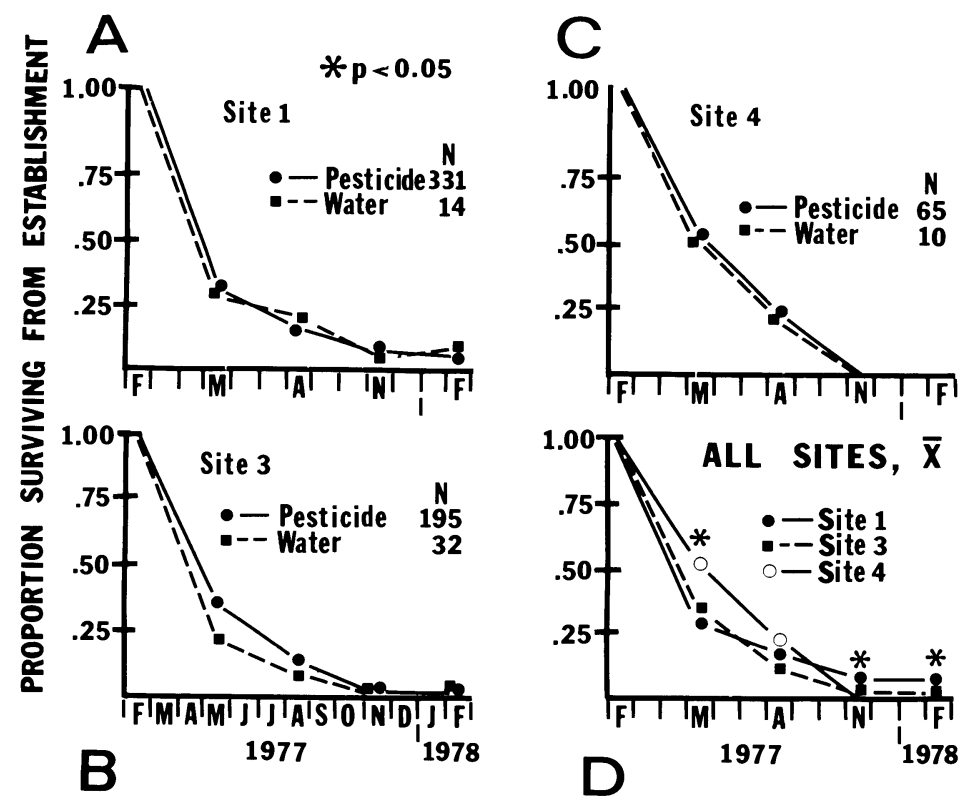

FIG. 6. Seedling survivorship over the 1st yr by treatment at each main site (A, B, C) and by site independent of treatment (D). Initial cohort size was the number of seedlings which were established in marked quadrats around the treatment plants by mid-February 1977. Differences were tested using Wilcoxon Matched-Pairs Signed-Ranks test.

mortality of the plant population under natural conditions (Harper 1969). Two key points emerge: (1) it was loss to the whole guild of seed predators, rather than to a particular insect species, which determined the net effect of predation on $H$. squarrosus recruitment, and (2) this operated in the context of the complex gradient to determine the numbers of plants at all sites along the transect.

2. Flower production. - The pattern in predation along the gradient (Fig. 4) was superimposed on trends in the components of seed production (Table 4). Flower initiation varied and was highest near the coast (Table 5B). This productive effort was the product of three factors: the number of (1) flowers or potential seeds in a flower head, (2) heads on a flowering branch, and (3) flowering branches on a plant. Each of these had its own distribution over the climatic gradient. Plants at the extremes of the gradient (I, IV), for example, had the most flowers per head (Table 4). In addition, while there were no significant differences in seed size between treatments, seed size peaked in the extreme zones I and IV ( $16 \%$ greater, $N=300)$. Plant size (Table 4A) and raceme size (Table 4B) peaked, instead, in zone II. Variation in flower production between portions of a climatic gradient may be a general phenomenon (Louda 1978).

3. Establishment and survival.-Seedling establishment as well as seedling, juvenile, and adult survival also varied over the gradient. A higher number of flowers initiated and seeds set were required for a control plant to establish each seedling in zones I and IV than in zone III, the area of highest adult plant occur- rence. The number of set, undamaged seeds required to establish a seedling did not vary between treatments but differed among zones; it was much higher in zone IV (92.0) than in either zone I (18.6) or III (19.2), suggesting that difficulty of germination and establishment augmented the effect of seed predation in the interior. There are several mechanisms that could explain the increase in the number of viable seeds after predation required to establish an $H$. squarrosus seedling in zone IV. These include significant differences in climatic conditions, in soil surface, or in postdispersal predation (Harper and White 1971, 1974, Harper 1977, S. M. Louda, personal observation). For example, snow between January 1974 and November 1978 was seen only in zone IV.

4. Seed destruction.-Higher seed production effort sustained higher predation rates along the complex gradient, contributing evidence of another type of spatial variation in insect herbivore-plant interactions. Herbivore pressure (or plant defense) has been shown to vary within habitats (Janzen 1970, 1971b, Platt et al. 1974, Handel 1976, Meehan et al. 1977), between habitats (Huffaker and Kennett 1959, Rochow 1970, Janzen 1971 $a, b, c$, 1975a, $b$, Stanton 1975, Bentley 1976, Louda 1978, S. M. Louda and J. E. Rodman, personal observation), or between geographic areas (Reichert 1958, Barnes 1968, Wapshere 1974, Levin 1976). The causes of higher intensity seed predation at the coast may include different levels of: (a) genetic (ecotypic) or physiological susceptibility, or (b) insect seed predator activity at the coast.

Genetic susceptibility seems to be an unlikely mech- 
TABLE 7. Distribution of seedlings surviving $1 \mathrm{yr}$, by initial density.

\begin{tabular}{ccccc}
\hline \hline & $\begin{array}{c}\text { Initial } \\
\text { number of } \\
\text { seedlings }\end{array}$ & $\begin{array}{c}\text { No. of } \\
\text { quad- } \\
\text { rats* }\end{array}$ & $\begin{array}{c}\text { Number } \\
\text { surviving } \\
\text { per quadrat }\end{array}$ \\
\hline Zone I, maritime $\dagger$ & $1-2$ & 7 & 1.0 & SE \\
\hline Zone III, transition & $3-6$ & 5 & 1.4 & 0.00 \\
& $7-14$ & 3 & 1.3 & 0.40 \\
& $15-30$ & 2 & 3.0 & 2.00 \\
& $1-2$ & 0 & 0 & $\ldots$ \\
& $3-6$ & 0 & 0 & $\ldots$ \\
& $7-14$ & 1 & 1.0 & 0.00 \\
& $15-30$ & 0 & 0 & $\ldots$ \\
\hline
\end{tabular}

* $50 \times 50 \mathrm{~cm}$ quadrats with any juvenile recruited.

$\dagger$ Kruskal-Wallis test, within-site in Zone I, $P<.05$.

anism in this case. Coastal (zone I) and inland (zone III) adult plants were similar to each other in growth and survivorship when grown in pots at a zone II site (S. M. Louda, personal observation). In addition, growth of seedlings from both coastal and inland seeds, that were planted at both zone I and zone III sites and protected from herbivores, was similar; growth depended on seed size, not site of seed origin (S. M. Louda, personal observation). The observations available suggest similar responses to similar conditions by plants from different zones. Nor does physiological susceptibility or ecotypic variation seem to be critical to an explanation of the pattern. The data on total flowers initiated per plant (Table 5B) as well as on seedling (Fig. 6), juvenile (Table 10), and adult (Table 10) survivorship all reflect response to physical

TABLE 8. Densities at successive developmental stages under unmanipulated and manipulated conditions.

\begin{tabular}{|c|c|c|c|c|c|}
\hline & \multicolumn{4}{|c|}{ Density by treatment } & \multirow[b]{3}{*}{$P^{*}$} \\
\hline & \multicolumn{2}{|c|}{$\begin{array}{l}\text { Control plots } \\
\text { or zone mean } \\
\end{array}$} & \multicolumn{2}{|c|}{$\begin{array}{l}\text { Pesticide } \\
\text { plots }\end{array}$} & \\
\hline & $\bar{x}$ & SE & $\bar{x}$ & SE & \\
\hline \multicolumn{6}{|l|}{ Zone I, maritime } \\
\hline Seedlings & 0.4 & 0.05 & 7.9 & 1.80 & 0.01 \\
\hline Juveniles & 0.02 & 0.02 & 0.6 & 0.12 & 0.05 \\
\hline Adults, zone mean & 0.9 & 0.07 & & & \\
\hline Adults, high density & 1.8 & 0.39 & & & \\
\hline \multicolumn{6}{|l|}{ Zone III, transition } \\
\hline Seedlings & 0.8 & 0.10 & 4.6 & 2.85 & 0.05 \\
\hline Juveniles & 0.0 & & 0.02 & 0.02 & \\
\hline Adults, zone mean & 1.0 & 0.06 & & & \\
\hline Adults, high density & 1.7 & 0.38 & & & \\
\hline \multicolumn{6}{|l|}{ Zone IV, interior } \\
\hline Seedlings & 0.2 & 0.05 & 1.6 & 0.55 & 0.05 \\
\hline Juveniles & 0.0 & & 0.0 & $\ldots$ & \\
\hline Adults, zone mean & 1.0 & 0.06 & & & \\
\hline Adults, high density & 2.0 & 0.45 & & & \\
\hline
\end{tabular}

* Mann-Whitney $U$ test on matched quadrats in the experiment.
TABLE 9. Fate of seedlings dying between February and May 1977, on the experimental plots.*

\begin{tabular}{lrcc}
\hline & $\begin{array}{c}\text { No. } \\
\text { dying }\end{array}$ & $\begin{array}{c}\text { Dried in } \\
\text { place }(\%)\end{array}$ & $\begin{array}{c}\text { Missing } \\
(\%)\end{array}$ \\
\hline Zone I, maritime & & & \\
$\quad$ Pesticide & 109 & 40.4 & 59.6 \\
$\quad$ Water control & 10 & 47.1 & 52.9 \\
$\quad$ Total & 119 & 43.8 & 56.2 \\
Zone III, transition & & & \\
$\quad$ Pesticide & 118 & 48.3 & 51.7 \\
$\quad$ Water control & 24 & 45.8 & 54.2 \\
$\quad$ Total & 142 & 47.0 & 53.0 \\
Zone IV, interior & & & \\
$\quad$ Pesticide & 29 & 24.1 & 75.9 \\
$\quad$ Water control & 8 & 37.5 & 62.5 \\
$\quad$ Total & 37 & 30.8 & 69.2 \\
\hline * Chi-square test of seedling fate among zones: $\chi_{3}^{2}=3.66$, \\
NS.
\end{tabular}

factors and all were higher, rather than lower, in the coastal zone.

Greater insect abundance and activity are the more likely cause of increased seed predation in the coastal area. Higher damage there reflects: (1) higher moth populations, and (2) higher plant quality at the coast.

Moth damage, by larval mining in the flower heads, was highest at the coast and decreased inland in parallel with the decrease in total insect damage. More moth larvae were found in coastal samples than in inland ones. In 1975, the proportion damaged by microlepidopterans varied from $40.0 \%$ in zone I, to $37 \%$ (II), $31.2 \%$ (III), and $25.4 \%$ in zone IV ( $N=13964$ heads). This was the only type of damage to seeds which showed a linear, decreasing trend in intensity over the climatic gradient from ocean to mountains (S. M. Louda, personal observation). In addition, the same moth types were found in samples from all climatic zones. Differential damage was the result of greater activity of at least three moth species at the coast (Louda 1978) rather than of specialized utilization by a single coastal species. Decreased amplitude of diurnal and seasonal physical parameters (Louda 1978), especially associated with fogs during the hot summer flight season, may be responsible for greater moth activity in the coastal areas.

Plant quality, measured as plant phenology, head size, proportion of seeds set, seed size, and total seeds initiated per plant, appears higher at the coast. Coastal plants are bigger (Table 4A). Furthermore, coastal plants initiate more flowers (Table 5B) and earlier (S. M. Louda, personal observation), and they set more seeds (Table 5B). Seeds of coastal plants tend to be bigger $(16 \%)$ and they occur in larger flower heads (Table 4B).

The data, in sum, suggest that differential seed predation by insects along the gradient was the proximate cause of the difference between observed and expect- 

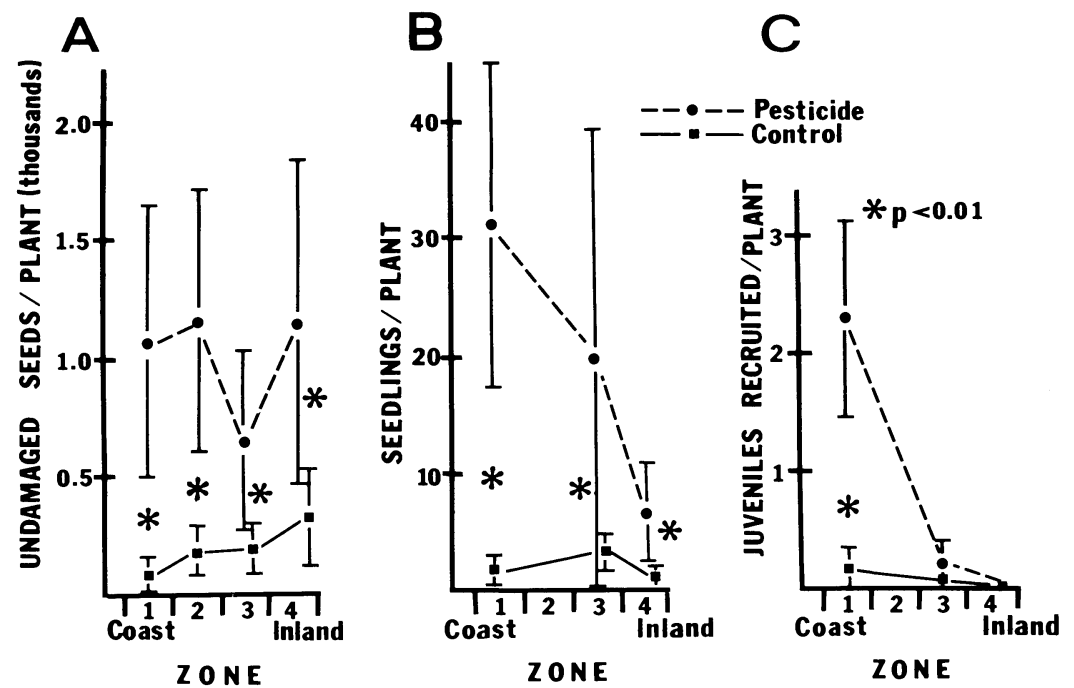

FIG. 7. Geographic patterns along the climatic gradient in pesticide-exclusion and water-control treatments (mean and $95 \%(\mathrm{CI})$ : in the production of undamaged, set seeds (A), in the establishment of seedlings (B), and in the recruitment of juvenile plants after $1 \mathrm{yr}(\mathrm{C})$. The Wilcoxon Two-sample Test was used to test differences $(*=P<.01)$.

ed abundance of $H$. squarrosus at the experimental sites from coast to mountains. The ultimate cause of higher loss to insect seed predators in coastal zones was a combination of: (1) physical factor variation; (2) microlepidopteran dynamics; and (3) morphological, developmental, and phenological characteristics of the host-plant along the gradient.

Compensation, carrying capacity, and exploitation of " surplus." - The broad question underlying the study was one of indigenous predator impact on native plant populations. The only data on seed predator effect on plant recruitment, so far, are in the biological control literature. The applied results are suggestive (Harper 1969); however, the interpretation of this information is complicated by the fact that it is taken on interactions outside the context of the native community in which they evolved. Unfortunately, when specialist herbivores are released to control introduced weeds, their competitors and predators are also left behind. The experiment presented here provides more complete information for a naturally occurring interaction.

This question, of the effect of seed predation on plants, is part of the general assessment of the net effect of exploitation on the dynamics of renewable resource populations. Predispersal seed predation, for example, is comparable in many ways to commercial fishing. The ecological questions are the same: how many individuals can be removed, at what time, in what age classes, and at what rate by various simultaneous consumers without driving the resource population extinct? Sufficiently intense early mortality, especially in the breeding grounds during the breeding season, influences standing stock, distribution, and age structure; it also affects the rate of recruitment and turnover for populations of: fish (Ricker 1954a, $b$, Murphy 1967), laboratory invertebrates (Slobodkin 1961), and terrestrial vertebrates (Errington 1948). Plant populations may now be added to this list.

Exploitation models, such as Ricker's $(1954 a, b)$, concentrate on effects of early mortality, the opposite of the logistic model (Frank 1960). Theoretical parallels between commercial utilization of fishes and predispersal insect exploitation of plants are clear in observations such as: "The simplest operational mechanism that fits Ricker's algebra is predation on eggs and larvae ..." (Murphy 1967). A key idea for this study is Ricker's prediction that differential mortality between areas should produce a spatial pattern of varying abundance in resource standing stock. The prediction is confirmed for predispersal seed predator impact on $H$. squarrosus over the climatic gradient.

Critical parameters determining the dynamics of a renewable resource population such as $H$. squarrosus include: (1) the rate of renewal of the resource, (2) the carrying capacity of the environment, and (3) the con-

TABLE 10. Juvenile and adult mortality of established plants at main sites after $1 \mathrm{yr}, 1977-1978$.

\begin{tabular}{|c|c|c|c|c|c|c|}
\hline & \multicolumn{3}{|c|}{ Juveniles* } & \multicolumn{3}{|c|}{ Adults $\dagger$} \\
\hline & $\begin{array}{c}\text { No. } \\
\text { of } \\
\text { plants }\end{array}$ & $\begin{array}{l}\text { No. } \\
\text { dy- } \\
\text { ing }\end{array}$ & $\begin{array}{l}\text { Per- } \\
\text { cent } \\
\text { dying }\end{array}$ & $\begin{array}{l}\text { No. } \\
\text { of } \\
\text { plants }\end{array}$ & $\begin{array}{l}\text { No. } \\
\text { dy- } \\
\text { ing }\end{array}$ & $\begin{array}{l}\text { Per- } \\
\text { cent } \\
\text { dying }\end{array}$ \\
\hline Zone I, maritime & 93 & 27 & 29.0 & 50 & 10 & 20.0 \\
\hline Zone III, transition & 95 & 40 & 42.1 & 50 & 18 & 36.0 \\
\hline Zone IV. interior & 63 & 25 & 39.7 & 50 & 16 & 32.0 \\
\hline
\end{tabular}

* February 1977-February 1978.

† March 1977-March 1978. 
version factor of prey into predators (see Mac Arthur 1960, 1972). The first two are particularly interesting in this case.

1. Resource population renewal.-Does predispersal attack select for compensation for bud, flower, or predispersal seed loss? or does it decrease renewal of the plant population? Compensatory vegetative growth is often seen with early clipping or defoliation (e.g., Jameson 1963, McNaughton 1979). Compensatory flower production has been reported in several cases (Lloyd et al. 1962, Adkisson et al. 1964, Harris 1974). Janzen (1971b) hypothesized that compensation might occur during maturation of the seed crop in response to predispersal destruction of seeds and fruits since predispersal loss "can be detected" by the parent plant. Response to detectable losses are possible in either the number or the size of seeds matured. Compensatory responses would decrease the quantitative impact of the earliest mortality by increasing the probability of seedling establishment (Janzen 1971b:467), either by increasing the number of propagules or by increasing the survivorship of germinated seedlings from bigger seeds (Salisbury 1942, Harper 1977).

No compensation occurred for flower or seed loss in this case. Consumption did not increase the total number of flowers initiated (Table 5B). In addition, since the removal of predispersal seed predators substantially increased the number of seeds matured (Table 5B), energy was not initially limiting seed crop size. Furthermore, variation in seed size between sites along the gradient was not inversely related to amount of seed destruction. The largest seeds occurred both at the coastal site, where loss to predators was greatest, and at the most interior site (IV), where loss to predators was lowest.

The trade-off between seed number and seed size predicted by Harris (1972) and others did not occur for $H$. squarrosus. A decrease in the number of seeds matured, as a result of insect attack, should cause an increase in the size of the remaining seeds if a tradeoff exists. Maun and Cavers (1971) found a 32\% increase in seed size with a $75 \%$ defloration of dock, Rumex crispus, and they found a progressive increase in average mass of seed as seed yield decreased through the removal of more and more flowers. My results, however, showed no difference in mean seed size or in seedling survivorship between treatments that differed by several orders of magnitude in the number of seeds matured. Observed seed size was independent of level of seed loss within a site. Differences in seed size between sites were maintained within sites on both pesticide and control plots, where levels of seed loss were very different. In addition, seedling survivorship was equal between treatments; this suggests that no change in seed size, leading to differences in seedling recruitment, occurred in relation to the number of seeds matured. So, in this case, some other factor besides number of seeds being ma- tured determines mean seed size and relative seedling survivorship in each region.

2. Carrying capacity.-Do predators take only "surplus" individuals (Pimentel 1961, Pimentel et al. 1963, Pimental and Soans 1971)? Or do they determine the distinction between "surplus" and "capital" individuals and, thus, the apparent carrying capacity of the environment for the prey population? On the time scale of this study, predispersal seed predators did more than take "surplus" seeds. Not all of the $\boldsymbol{H}$. squarrosus individuals destroyed by seed predators in the coastal zone were "doomed to die." In fact, when seed individuals were allowed to escape predation, significantly more became established and were recruited to the adult population, especially in the coastal zone. Predation reduced recruitment of the plant prey species to below the rate that would lead to sustainable adult density, thus "denting the capital." On the longer time scale, the predispersal seed predators appeared to be exerting enough pressure so that adaptation by $H$. squarrosus towards greater escape from predators should occur, at least in the coast zones.

\section{Acknowledgments}

Many people contributed to this research and I am immensely grateful. I became interested in the question through discussions with W. W. Murdoch and R. D. Goeden. J. H. Connell impressed me with the necessity of field experimentation. B. D. Collier, R. F. Luck, and P. H. Zedler alternately guided, challenged, and encouraged me. In addition, M. D. Atkins, C. F. Cooper, G. W. Cox, T. A. Ebert, D. A. Farris, L. R. Fox, W. E. Hazen, J. Kummerow, and D. Potts provided analytical or experimental advice. J. Clark, W. H. Ewert, G. Gordh, J. Hall, R. W. Hodges, G. Marsh, and J. A. Powell verified insect identifications. Comments by J. Antonovics, B. D. Collier, S. N. Handel, S. Mazer, K. R. McKaye, M. Price, R. B. Root, B. Tiffney, and N. Waser improved the manuscript. My thanks are extended also to the friends and family members who helped gather data; G. A. Baker and G. B. Harvey contributed exceptionally enthusiastic and persistent assistance. Research support was provided by the Joint Doctoral Program in Ecology (San Diego State University/University of California, Riverside) and a National Science Foundation Doctoral Dissertation Improvement Grant. The manuscript was written while I was supported by the F. B. and E. D. Brown Postdoctoral Fellowship in Botany at Yale University.

\section{Literature Cited}

Adkisson, P. L., R. L. Hanna, and C. F. Bailey. 1964. Estimates of the number of Heliothis larvae per acre of cotton and their relation to the fruiting cycle and yield of the host. Journal of Economic Entomology 57:657-663.

Barbour, M. G., J. H. Burk, and W. D. Pitts. 1980. Terrestrial plant ecology. Benjamin/Cummings, Menlo Park, California, USA.

Barbour, M. G., and J. Major. 1977. Terrestrial vegetation of California. Wiley-Interscience, New York, New York, USA.

Barnes, E. H. 1968. Atlas and manual of plant pathology. Appleton-Century-Crofts, New York, New York, USA.

Bentley, B. L. 1976. Plants bearing extrafloral nectaries and the associated ant community: interhabitat differences in the reduction of herbivore damage. Ecology 57:815-820. 
Billings, D. W. 1964. Plants and the ecosystem. Wadsworth, Belmont, California, USA.

Breedlove, D. E., and P. R. Ehrlich. 1968. Plant-herbivore coevolution: lupines and lycaenids. Science 162:671-672.

Breedlove, D. E., and P. R. Ehrlich. 1972. Coevolution: patterns of legume predation by a lycaenid butterfly. Oecologia 10:99-104.

Brooks, J. L., and S. I. Dodson. 1965. Predation, body size and composition of plankton. Science 150:28-35.

Browne, R. H. 1979. On visual assessment of the significance of a mean difference. Biometrics 35:657-665.

Cantlon, J. E. 1969. The stability of natural populations and their sensitivity to technology. Brookhaven Symposium in Biology 22: 197-205.

Cates, R. G., and D. F. Rhoades. 1976. Patterns in the production of antiherbivore chemical defense in plant communities. Biochemical Systematics and Ecology 5:185193.

Christianson, L. D., and R. H. Foote. 1960. Biology of fruit flies. Annual Review of Entomology 4:171-192.

Close, D. H., editor. 1970. Climates of San Diego County. University of California, Agricultural Extension Service, San Diego, California, USA.

Connell, J. H. 1970. A predator-prey system in the marine intertidal region. I. Balanus glandula and several predatory species of Thais. Ecological Monographs 40:49-78.

1971. On the role of natural enemies in preventing competitive exclusion in some marine animals and in rain forest trees. Pages 298-312 in P. J. den Boer and G. Gradwell, editors. Dynamics of populations. Proceeding of the Advanced Study Institute on Dynamics of Numbers in Populations (Öosterbeek, 1970). Centre for Agricultural Publishing and Documentation, Wageningen, The Netherlands.

Darwin, C. (1958) (1859). The origin of species. A Mentor Book. The New American Library of World Literature, New York, New York, USA.

Dethier, V. G. 1970. Chemical interactions between plants and insects. Pages 83-102 in E. Sondheimer and J. B. Simeone, editors. Chemical ecology. Academic Press, New York, New York, USA.

Ehrlich, P. R., and P. H. Raven. 1965. Butterflies and plants: a study in coevolution. Evolution 18:586-608.

Ehrlich, P. R., and P. H. Raven. 1967. Butterflies and plants. Scientific American 216: 105-113.

Errington, P. L. 1946. Predation and vertebrate populations. Quarterly Review of Biology 21:145-177, and 221-245.

Feeny, P. 1975. Biochemical coevolution between plants and their insect herbivores. Pages 3-19 in L. E. Gilbert and P. H. Raven, editors. Coevolution of plants and animals. University of Texas Press, Austin, Texas, USA.

1976. Plant apparency and chemical defense. Recent Advances in Phytochemistry 10:1-40.

Frank, P. W. 1960. Prediction of population growth form in Daphnia pulex cultures. American Naturalist 94:357-372.

Gilbert. D. E. 1970. California plantclimates. Pages 13-17 in D. H. Close, editor. Climates of San Diego County. University of California, Agricultural Extension Service, San Diego, California, USA.

Goeden, R. D. 1978. Biological control of weeds. Pages 357413 in C. P. Clausen, editor. Introduced parasites and predators of arthropod pests and weeds: a world review. Agricultural Research Service Handbook 480, United States Department of Agriculture, United States Government Printing Office, Washington, D.C., USA.

Hall, H. M. 1928. The genus Haplopappus. Publication Number 389, Carnegie Institute, Washington, D.C., USA.

Handel, S. N. 1976. Population ecology of three woodland Carex species. Dissertation. Cornell University, Ithaca, New York. USA.
Hanes, T. L. 1977. California chaparral. Pages 418-469 in M. Barbour and J. Major, editors. Terrestrial vegetation of California. Wiley-Interscience, New York, New York, USA.

Hare, D., and D. J. Futuyma. 1978. Different effects of variation in Xanthium strumarium L. (Compositae) on two insect seed predators. Oecologia (Berlin) 37:109-120.

Harper, J. L. 1969. The role of predation in vegetation diversity. Brookhaven Symposium in Biology 22:48-62.

. 1977. The population biology of plants. Academic Press, New York, New York, USA.

Harper, J. L., and J. White. 1971. The dynamics of plant populations. Pages 41-43 in P. J. den Boer and G. Gradwell, editors. Proceeding of the Advanced Study Institute on Dynamics of Numbers in Populations (Öosterbeek, 1970). Centre for Agricultural Publishing and Documentation, Wageningen, The Netherlands.

Harper, J. L., and J. White. 1974. The demography of plants. Annual Review of Ecology and Systematics 5:419463.

Harper, J. L., J. T. Williams, and G. R. Sagar. 1965. The behavior of seeds in the soil. I. Heterogeneity of soil surfaces and its role in determining the establishment of plants from seed. Journal of Ecology 53:273-286.

Harris, P. 1972. Insects in the population dynamics of plants. Pages 201-210 in H. F. van Emden, editor. Insect/ plant relationships. Blackwell Scientific Publications, Oxford, England.

1974. A possible explanation of plant yield increases following insect damage. Agroecosystems 1:219-225.

Hubbs, C. L., and A. Perlmutter. 1942. Biometric comparison of several samples, with particular reference to racial investigation. American Naturalist 76:582-592.

Huffaker, C. B., and C. E. Kennett. 1959. A ten-year study of vegetational changes associated with biological control of Klamath weed. Journal of Range Management 12:69-82.

Jameson, D. A. 1963. Responses of individual plants to harvesting. Botanical Review 29:532-594.

Janzen, D. H. 1969. Seed-eaters versus seed size, number, toxicity and dispersal. Evolution 23:1-27.

1970. Herbivores and the number of tree species in tropical forests. American Naturalist 104:501-528.

- 1971a. Escape of Cassia grandis L. beans from predators in time and space. Ecology 52:964-979.

1971 b. Seed predation by animals. Annual Review of Ecology and Systematics 2:465-492.

1971c. Escape of juvenile Dioclea megacarpa (Leguminosae) vines from predators in a deciduous tropical forest. American Naturalist 105:97-112.

1975a. Intra- and interhabitat variations in Guazuma ulmifolia (Sterculiaceae) seed predation by Amblycerus cistelinus (Bruchidae) in Costa Rica. Ecology 56:10091013.

1975b. Behavior of Hymenaea courbaril when its predispersal seed predator is absent. Science 189:145-147. pred $1975 \mathrm{c}$. Interactions of seeds and their insect predators/parasitoids in a tropical deciduous forest. Pages 154 186 in P. W. Price, editor. Evolutionary strategies of parasitic insects and mites. Plenum Press, New York, New York, USA.

Levin, D. A. 1976. Alkaloid-bearing plants: an ecogeographic perspective. American Naturalist 110:261-284.

Lewis, T. 1973. Thrips: their biology, ecology and economic importance. Academic Press, New York, New York, USA.

Lloyd, E. P., M. E. Merkl, and G. B. Crowe. 1962. The effect of boll weevil infestations on yield and quality of cotton. Journal of Economic Entomology 55:225-227.

Louda, S. M. 1978. A test of predispersal seed predation in the population dynamics of Haplopappus (Asteraceae). 
Dissertation. University of California, Riverside, California, and San Diego State University, San Diego, California, USA.

. 1982, in press. Limitation of the recruitment of the shrub Haplopappus squarrosus (Asteraceae) by flowerand seed-feeding insects. Journal of Ecology.

Mac Arthur, R. H. 1960. On the relation between reproductive value and optimal predation. Proceedings of the $\mathrm{Na}$ tional Academy of Sciences (Philadelphia) 46:143-145.

. 1972. Geographical ecology. Harper and Row, New York, New York, USA.

Maiorana, V. C. 1981. Herbivory in sun and shade. Biological Journal of the Linnean Society 15:151-156.

Manley, G. V., J. W. Butcher, and J. E. Cantlon. 1975. Relationship of insects to distribution and abundance of Melampyrum lineare (Scrophulariaceae). Pedobiologia 15(6):385-404.

Maun, M. A., and P. B. Cavers. 1971. Seed production and dormancy in Rumex crispus. I. The effects of removal of cauline leaves at anthesis. Canadian Journal of Botany 49: 1123-1130.

McNaughton, S. J. 1979. Grazing as an optimization process: grass-ungulate relationships in the Serengeti. American Naturalist 113:691-703.

Mech, L. D. 1966. The wolves of Isle Royale. Fauna Series Number 7, United States National Park Service, Washington, D.C., USA.

Meehan, T., P. W. Rundel, R. Ambrose, G. Baker, and A. Rappoport. 1977. The influence of intense selective browsing by pocket mice (Perognathus) on the spatial distribution of Polygala deserticum in Baja, California. American Midland Naturalist 97:489-495.

Miller, P. C., D. E. Bradbury, E. Hajek, V. LaMarche, and N.J.W. Thrower. 1977. Past and present environment. Pages 27-72 in H. A. Mooney, editor. Convergent evolution in Chile and California: Mediterranean climate ecosystems. Dowden, Hutchison, and Ross, Stroudsburg, Pennsylvania, USA.

Mooney, H. A. 1977. Southern coastal scrub. Pages 471489 in M. Barbour and J. Major, editors. Terrestrial vegetation of California. Wiley-Interscience, New York, New York, USA.

Munz, P. A., and D. C. Keck. 1970. A California flora. University of California Press, Berkeley, California, USA.

Murphy, G. I. 1967. Vital statistics of the Pacific sardine (Sardinops caerulea) and the population consequences. Ecology 48:731-736.

Paine, R. T. 1966. Food web complexity and species diversity. American Naturalist 100:65-75.

Pimentel, D. 1961. Animal population regulation by the genetic feed-back mechanism. American Naturalist 95:65-79.

Pimentel, D., W. P. Nagel, and J. L. Madden. 1963. Spacetime structure of the environment and the survival of parasite-host systems. American Naturalist 97:141-167.

Pimentel, D., and A. B. Soans. 1971. Animal populations regulated to carrying capacity of plant host by genetic feedback. Pages 313-326 in P. J. den Boer and G. Gradwell, editors. Proceeding of the Advanced Study Institute on Dynamics of Numbers in Populations (Öosterbeek, 1970).
Centre for Agricultural Publishing and Documentation, Wageningen, The Netherlands.

Platt, W. J., G. R. Hill, and S. Clark. 1974. Seed production in a prairie legume (Astragalus canadensis L.): interactions between pollination, predispersal seed predation, and plant density. Oecologia (Berlin) 17:55-63.

Powell, J. A. 1964. Biological and taxonomic studies on Tortricine moths, with reference to the species in California. Number 32, University of California Publications in Entomology, Berkeley, California, USA.

Reichert, I. 1958. Fungi and plant diseases in relation to biogeography. Transactions, New York Academy of Science, Series II, 20:333-339.

Rhoades, D. F., and R. G. Cates. 1976. Toward a general theory of plant antiherbivore chemistry. Recent Advances in Phytochemistry 10:168-213.

Ricker, W. E. 1954a. Stock and recruitment. Journal of the Fisheries Research Board of Canada 11:559-623.

- 1954b. Effects of compensatory mortality upon population abundance. Journal of Wildlife Management 18:4551.

Rochow, T. F. 1970. Ecological investigations of Thlaspi alpestre L. along an altitudinal gradient in the central Rocky Mountains. Ecology 51:649-659.

Rosenthal, G. A., and D. H. Janzen, editors. 1979. Herbivores: their interaction with secondary plant metabolites. Academic Press, New York, New York, USA.

Salisbury, E. J. 1942. The reproductive capacity of plants: studies in quantitative biology. Bell, London, England.

Simpson, G. G., A. Roe, and R. C. Lewontin. 1960. Quantitative zoology. Harcourt, Brace, and World, New York, New York, USA.

Slobodkin, L. B. 1961. Growth and regulation of animal populations. Holt, Rinehart and Winston, New York, New York, USA.

Sokal, R. R., and F. J. Rohlf. 1969. Biometry. W. H. Freeman, San Francisco, California, USA.

Stanton, N. 1975. Herbivore pressure on two types of tropical forest. Biotropica $7: 8-11$.

Vogl, R. J., and P. K. Schorr. 1972. Fire and manzanita chaparral in the San Jacinto Mountains, California. Ecology 53:1179-1188.

Waloff, N., and O. W. Richards. 1977. The effect of insect fauna on growth, mortality and natality of broom, Sarothamnus scoparius. Journal of Applied Ecology 14:787798.

Wapshere, A. J. 1974. Host specificity of phytophagous organisms and the evolutionary centers of plant genera or subgenera. Entomophaga 19:301-309.

Whittaker, R. H. 1967. Gradient analysis of vegetation. Biological Reviews 42:207-264.

- 1970. Communities and ecosystems. Macmillan, London, England.

Whittaker, R. H., and P. Feeny. 1971. Allelochemics: chemical interactions between species. Science 171:757-770.

Willson, M. F. 1973. Evolutionary ecology of plants: a review. Part V: plant/animal interactions. The Biologist 55:89-105. 